\title{
Observational and experimental evaluation of hemiparasite resistance in trees in the urban afforestation of Santarém, Pará, Brazil
}

\author{
Francisco Pinheiro da SILVA ${ }^{1,2}$, Rodrigo Ferreira FADINI ${ }^{1^{*}}$ \\ 1 Universidade Federal do Oeste do Pará, Instituto de Biodiversidade e Florestas, Rua Vera Paz, s/n, CEP 68100-000, Santarém, Pará, Brazil \\ 2 Prefeitura Municipal de Mojuí dos Campos, Secretaria Municipal de Meio Ambiente, Rua Estrada de Rodagem, s/n, CEP 68129-000, Mojuí dos Campos, Pará, Brazil \\ *Corresponding author: rfadini@gmail.com
}

\section{ABSTRACT}

One of the problems affecting the quality of urban trees is their infestation by mistletoes (aerial hemiparasite plants of the order Santalales). Identification of the main types of trees infested, and of the causes of infestation patterns, can help infestation control and the planning of efficient planting regimes. In this sense, the aim of this study was to evaluate the patterns of hemiparasite infestation in trees in an Amazonian urban environment. We aimed to answer (1) which species of mistletoes occur on urban trees in the city of Santarém, in the Brazilian Amazon; (2) what is the proportion and intensity of infestation on infected trees; and (3) if differences in infestation rates among tree species can be explained by mistletoe-tree compatibility. We assessed mistletoe incidence and intensity of infestation on trees in the main avenues of the city. To evaluate the role of mistletoe-tree compatibility in the observed parasitism patterns, we carried out a seed inoculation experiment with seeds of the most abundant mistletoe, Passovia theloneura. Seeds were planted on three tree species (Andira inermis, Handroanthus serratifolius, and Mangifera indica). The overall infestation rate was $19.3 \%$, with exotic tree species more infested than natives. The experiment showed that incompatibility between $P$. theloneura and the native $H$. serratifolius is primarily responsible for the observed non-infestation. Mistletoes germinated on $A$. inermis grew better than those on $M$. indica, contrary to the infestation prevalence found in the field, suggesting that patterns of infestation are also influenced by seed deposition processes.

KEYWORDS: Loranthaceae, mistletoe, tree parasites, urban silviculture

\section{Avaliação observacional e experimental da resistência a hemiparasitas em árvores da arborização urbana de Santarém, Pará, Brasil}

\section{RESUMO}

Um dos problemas que afetam a qualidade das árvores urbanas é sua infestação por ervas-de-passarinho (hemiparasitas aéreas da ordem Santalales). Identificação das principais espécies de árvores infestadas e das causas da infestaçáo pode ajudar a controlar as ervas-de-passarinho e orientar o plantio de novas espécies de árvores. Nesse sentido, o objetivo deste estudo foi avaliar o padrão de infestação de hemiparasitas em árvores em um ambiente urbano da Amazônia. Nós buscamos responder: (1) quais espécies de ervas-de-passarinho ocorrem nas árvores urbanas da cidade de Santarém, na Amazônia Brasileira, (2) qual é a proporção e intensidade de infestação nas árvores afetadas e (3) se diferenças nas taxas de infestação entre as espécies de árvores podem ser explicadas pela compatibilidade entre ervas-de-passarinho e hospedeiro. Nós amostramos árvores nas principais avenidas da cidade. Para avaliar o papel da compatibilidade entre a erva-de-passarinho e o hospedeiro nos padrôes de parasitismo observados, conduzimos um experimento de inoculação de sementes com a erva-de-passarinho mais abundante, Passovia theloneura. Sementes foram plantadas em três espécies de hospedeiros (Andira inermis, Handroanthus serratifolius e Mangifera indica). A taxa de infestação foi de 19,3\%, com espécies exóticas mais infestadas do que as nativas. O experimento mostrou que a incompatibilidade entre $P$. theloneura e a nativa $H$. serratifolius é o principal fator responsável por sua não infestação. As ervas-de-passarinho que germinaram em $A$. inermis cresceram melhor do que aquelas em $M$. indica, contrário à prevalência de infestação encontrada no campo, o que sugere que os padróes de infestação são também influenciados por processos de deposição de sementes.

PALAVRAS-CHAVE: Loranthaceae, erva-de-passarinho, parasitas de árvores, silvicultura urbana 


\section{INTRODUCTION}

Urban forestry plays an important role in cities, from providing environmental goods and services to the human population, to preserving wildlife (Pivetta and Silva-Filho 2002; Faria et al. 2007). Studies show that increasing urban afforestation can raise the life quality of inhabitants, since trees provide shade for pedestrians, improve air quality, reduce noise pollution and alleviate the thermal environment (Silva et al. 2002; Loboda and De Angelis 2005). However, urban afforestation faces a number of problems, including infestation of trees by mistletoes (Watson and Martinez-Trinidad 2006; Leal et al. 2006; Rotta et al. 2006).

Mistletoes are aerial hemiparasitic plants of the order Santalales. Their sticky seeds attach to branches and trunks of trees and shrubs after being disseminated by dispersing agents, mainly birds (Monteiro et al. 1992). There are approximately 1,600 mistletoe species worldwide (Nickrent 2011), of which 200 occur in Brazil, distributed in three botanical families: Santalaceae, Loranthaceae and Viscaceae (Arruda et al. 2012). Once established on their hosts, mistletoes parasite and compete with them for water and nutrients, and reduce host photosynthetic efficiency (Watson 2001). Thus, trees infested with mistletoes may be more vulnerable to insect attack and to environmental stress (Mathiasen et al. 2008).

Several factors may influence the successful colonization of hosts by mistletoes, including disperser behavior and host compatibility (Roxburgh and Nicolson 2005). The behavior of the disperser is responsible for determining on which hosts mistletoe seeds will be deposited and how often, since birds may prefer to perch on certain host species depending on their height or canopy architecture (Roxburgh and Nicolson 2005). However, the establishment only fully occurs when the deposited mistletoe is biologically, chemically and physically compatible with the host; it is these factors in combination that predispose a tree to be infected (or not) by a mistletoe species (Fadini 2011).

Despite the negative aspects mentioned, mistletoes can also play an important role in urban ecosystems as they provide a food source for several animals (Cazetta and Galetti 2003; Modro et al. 2011; Maruyama et al. 2012), in addition to providing physical support for the construction of nests by several bird species (Cooney et al. 2006). As suppression of the mistletoes in urban landscapes may compromise the fauna that depends on them, management of persisting urban mistletoe populations may be a better option (Watson 2001), and, consequently, information on the prevalence and intensity of mistletoe infection of urban trees is highly useful in urban forestry, as it facilitates more efficient management and monitoring of these plants.
Urban afforestation of Santarém city, Pará State, in the eastern Brazilian Amazon, presents high infestation rates by mistletoes. This pattern, which is similar to other main cities in the region (Manaus and Belém), may result from the planting of exotic species, as suggested for other localities (Gairola $e t$ al. 2013; Diáz-Limón et al. 2016), together with the lack of adequate management. In this regard, the main objective of this study was to describe the pattern of infestation of urban trees by mistletoes in Santarém, and to evaluate one of the mechanisms that determine this pattern - the compatibility between mistletoes and host. The study aimed at answering the following questions: (1) Which species of mistletoes are found on urban trees in Santarem? (2) What is the proportion of infested trees and what is the average intensity of parasitism? and (3) Can differences in infestation rates among host species be explained by their compatibility with mistletoes?

\section{MATERIALS AND METHODS}

\section{Study area}

The municipality of Santarém (2'24'52"S, 5442'36"W) has an area of $22,886.76 \mathrm{~km}^{2}$ and a population of 294,580 inhabitants, approximately $75 \%$ of which live in urban areas (IBGE 2010). The climate, according to the Köppen classification, is type Am (Alvares et al. 2014), with an average air temperature between $25^{\circ} \mathrm{C}$ and $28^{\circ} \mathrm{C}$, average relative air humidity of $86 \%$, and annual mean rainfall of $1920 \mathrm{~mm}$. The rainy season occurs between December and May, and the dry season (<60 mm monthly) between June and November (Santarém 2015). Santarém is considered deficient in urban afforestation (Uchôa 2011). The tree species more frequently planted in public spaces (squares, avenues, etc.) are Mangifera indica [L.], Syzygium malaccense [(L.) Merr. \& L.M.Perry], Ficus benjamina [L.], Licania tomentosa [(Benth.) Fritsch] and Handroanthus serratifolius [(Vahl) S.Grose] (Silva et al. unpublished data).

\section{Data collection}

We selected three large and adjacent main avenues in the urban center of Santarém (Mendonça Furtado, Presidente Vargas and Marechal Rondon avenues) for our survey (Figure 1). The survey distance along each avenue was of approximately $3 \mathrm{~km}$. These avenues play an important role in the urban landscape of the city, because they are among the few avenues that have central tree lines separating the two-directional lanes. Preliminary observations indicated that mistletoes are present in trees at various points along these avenues. Only trees located in the public areas were included, both in the tree lines and on the sidewalks. Geographic coordinates, height $(\mathrm{m})$ and diameter at $30 \mathrm{~cm}$ above the ground (DAG) were measured for all trees with height equal to or greater than 3 meters and with a distance greater than 5 meters from the last tree sampled. The height of each host 
tree was calculated with a clinometer. Encountered mistletoes were identified with an identification key made by a specialist (C. S. Caires, personal communication). Infected trees were classified according to the degree of infestation, using five classes: I (without infestation), II (1 to $25 \%$ of the canopy infested); III (26-50\%), IV (51-75\%) and V (76-100\%). This classification is an adaptation of a method widely used in plant phenology studies (Fournier 1974).

\section{Seed germination, seedling establishment and growth}

Following the field survey, three species of trees were selected for a seed inoculation experiment. Two of the tree species were mistletoe hosts ( $M$. indica and Andira inermis [W.Wright) DC.]), while the third was not recorded with any mistletoe infestation (H. serratifolius). Ten non-infested individuals of each of these three species were selected and manually inoculated with seeds of Passovia theloneura (Eichler) Tiegh (Loranthaceae), the species of mistletoe that was most frequently found during the field survey. The inoculated trees were haphazardly distributed through the streets of the municipality, and had canopy heights of between 3 and $6 \mathrm{~m}$. In each tree, five branches with a diameter of 1-1.5 $\mathrm{cm}$ were selected, and two mistletoe seeds were planted on each branch, separated by $20 \mathrm{~cm}$. The chosen branches had exposed positions within the canopy and were at heights of between 3 to $5 \mathrm{~m}$.

The seeds of $P$. theloneura used in the experiment were collected from different host plants located along the surveyed avenues. The seeds were placed in a container with water for a period of 10 hours, after which their exocarps were removed, and the seeds were inoculated onto the trees. One week after planting, seed survival was evaluated, as well as germination (determined by the production of foliaceous cotyledons). One month after planting, survival and seed establishment were again evaluated, focusing on penetration of the haustorium and presence of epicortical roots. The haustorium is an organ that attaches to host plants and contacts their vessels to extract water and minerals, while epicortical roots grow along the tree branches, forming new secondary haustoria (Calvin and Wilson 2006). Established plants were checked monthly until the sixth month, when they were removed from their hosts and the following measures were taken: (1) length $(\mathrm{cm})$ of epicortical roots and main branch; (2) fresh mass (g) of epicortical roots and aerial parts, and (3) dried mass (g) of epicortical roots and aerial parts, after being oven dried at $60^{\circ} \mathrm{C}$ for $2-3$ days.

\section{Statistical analysis}

The expected frequency of infestation for each host species was calculated by dividing the total number of individuals

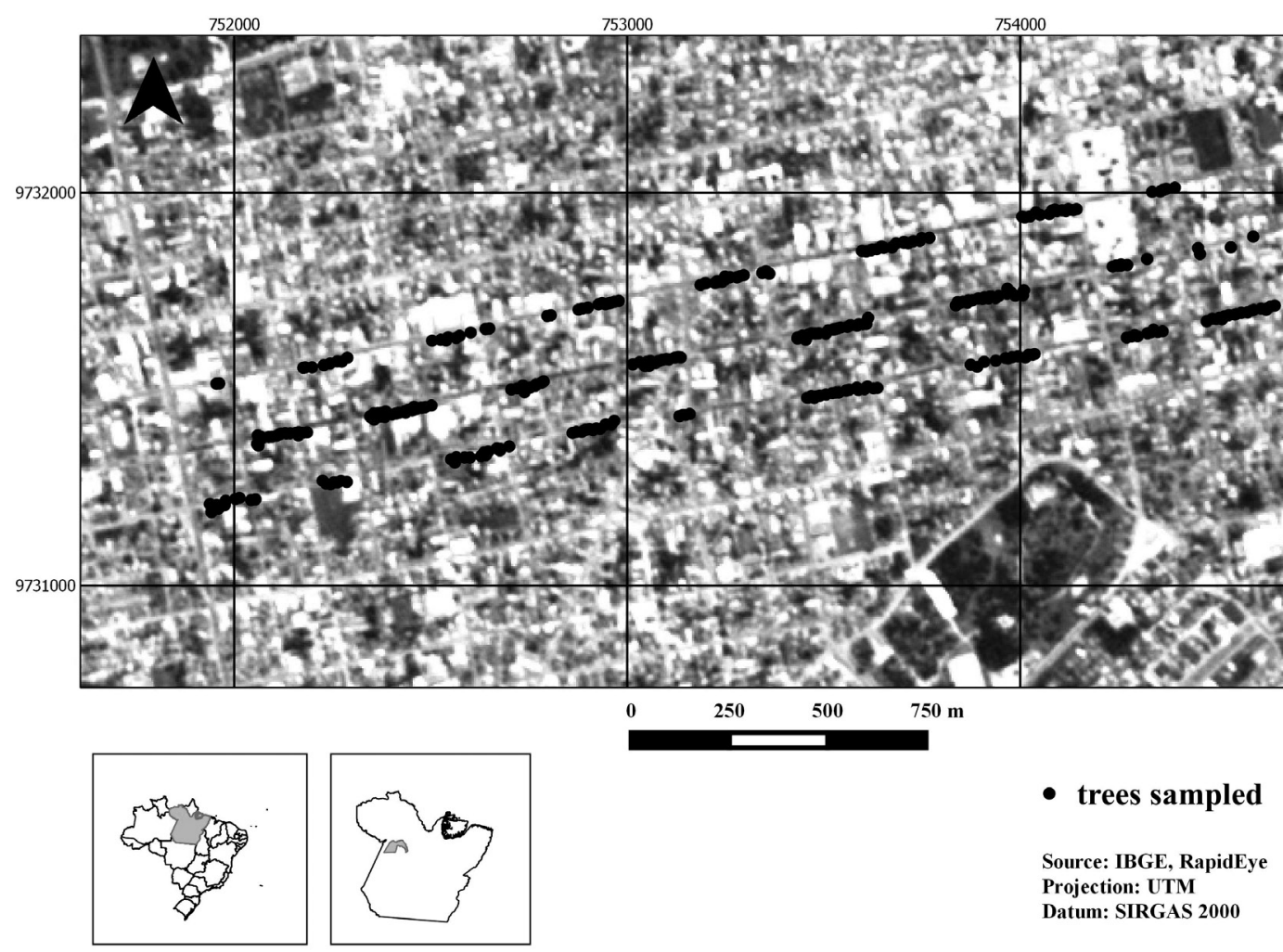

Figure 1. Map of the central urban area of the city of Santarém (Pará State, Brazil), showing the sampled trees (black dots) along the three surveyed avenues. 
infected by the total number of individuals surveyed. We compared the observed and expected frequency of infestation using a chi-squared test. The experimental germination rate of P. theloneura was compared among the three host species using ANOVA $(\mathrm{p}<0.05)$. Passovia theloneura seedlings survived for six months on only two of the tested host-tree species. A $\mathrm{t}$-test for independent samples was used to evaluate differences in growth of planted mistletoe specimens on the two host species. When necessary, the data were log-transformed to meet the requirements of statistical tests (homoscedasticity and normality). Data were analyzed using $\mathrm{R}$ software ( $\mathrm{R}$ Development Core Team 2015).

\section{RESULTS}

A total of 310 trees belonging to 10 families, 19 genera and 22 species were sampled, of which $M$. indica (47\%), $H$. serratifolius (23\%) and Ficus benjamina L. (9\%) were the most abundant (Table 1). Of the total individuals sampled, 19.3\% were infested by mistletoes. Of the nine infested host species, seven $(77 \%)$ were exotic. Passovia theloneura was the most abundant mistletoe, parasitizing 59 individuals, while the second most abundant hemiparasite, Oryctanthus florulentus (Rich.) Tiegh, was found on four trees. Therefore, we further analyzed only the data for $P$. theloneura.

Mangifera indica, S. malaccense and Tabebuia aurea [(Silva Manso) Benth. \& Hook.f. ex S.Moore] had far more individuals infected by $P$. theloneura than expected from their relative abundance (Figure 2). Ficus benjamina had a lower number of infected individuals than expected, whereas no infestations were recorded for $H$. serratifolius.

Results of infestation intensity for the four most abundant host species showed that, while there were a few highly infested hosts (classes IV and V), many potential hosts were either not infested (class I) or were infested with low intensity (class II) (Figure 3). Mangifera indica was the only species that had individuals in all classes of infestation intensity.

There was no significant difference in the germination rates of $P$. theloneura seeds inoculated on the three host species at one week after planting $(\mathrm{F}=0.15, \mathrm{p}=0.858)$. The percentage of germinated seeds for $A$. inermis, $M$. indica and H. serratifolius was $81 \%, 79 \%$ and $83 \%$, respectively. At the end of six months, 3.6 times more seedlings were established on $A$. inermis than on $M$. indica, and no seedlings were established in $H$. serratifolius (Figure 4).

Growth of $P$. theloneura seedlings varied between host species: those planted on $A$. inermis showed aerial and epicortical root development, while those on $M$. indica showed only shoot development (Table 2). Main branch length of seedlings also differed between the two host species ( $\log$ transformed data, $\mathrm{t}=4.86, \mathrm{~d} . \mathrm{f}=18.56, \mathrm{p}=0.0001)$, with the average length for seedlings on $A$. inermis being five times greater than for those on $M$. indica. The fresh mass of the twigs from seedlings on $A$. inermis was twenty times greater than from those on $M$. indica $(\mathrm{t}=4.14$, d.f $=28$, $\mathrm{p}$ $=0.0002)$. Seedlings on $A$. inermis had an average dry mass thirty times greater than seedlings on $M$. indica $(\mathrm{t}=3.98$, d.f $=28.1, \mathrm{p}=0.0004)$.

Table 1. List of tree species found on the three surveyed avenues of the city of Santarém, including origin, number of individuals surveyed, average height and average DAG (diameter at $30 \mathrm{~cm}$ above the ground) of the individuals surveyed, and frequency of infected individuals. Family names follow APG IV (APG 2016). Species were classified as "native" or "exotic" according to Flora do Brasil 2020 (http://floradobrasil.jbri.gov.br/).

\begin{tabular}{|c|c|c|c|c|c|c|}
\hline Family & Scientific Name & Origin & $\mathrm{N}$ individuals & Height $(m) \pm$ DPSD & $\mathrm{DAG}(\mathrm{m}) \pm \mathrm{SDDP}$ & $\begin{array}{l}\text { Infestation } \\
\text { frequency (\%) }\end{array}$ \\
\hline \multirow{2}{*}{ Anacardiaceae } & Anacardium ocidentale L. & Native & 4 & $8.2 \pm 3.8$ & $34.70 \pm 18.0$ & \\
\hline & Mangifera indica L. & Exotic & 145 & $8.6 \pm 2.8$ & $37.43 \pm 15.0$ & 29 \\
\hline \multirow{4}{*}{ Bignoniaceae } & Crescentia cujete L. & Exotic & 2 & $3.9 \pm 0.2$ & $30.88 \pm 12.2$ & \\
\hline & Handroanthus serratifolius (Vahl) S.Grose & Native & 71 & $8.9 \pm 2.4$ & $21.62 \pm 6.2$ & \\
\hline & Handroanthus sp. & Native & 1 & 3.50 & 7.00 & \\
\hline & $\begin{array}{l}\text { Tabebuia aurea (Silva Manso) } \\
\text { Benth. \& Hook.f. ex S.Moore }\end{array}$ & Native & 4 & $8.3 \pm 0.9$ & $29.68 \pm 4.8$ & 75 \\
\hline \multirow{2}{*}{ Chrysobalanaceae } & Couepia bracteosa Benth. & Native & 1 & 6.6 & 10.50 & \\
\hline & Licania tomentosa (Benth.) Fritsch & Native & 7 & $5.2 \pm 1.7$ & $19.33 \pm 9.2$ & \\
\hline Combretaceae & Terminalia catappa L. & Exotic & 4 & $8.3 \pm 2.8$ & $30.16 \pm 14.6$ & 25 \\
\hline \multirow{5}{*}{ Fabaceae } & Pithecellobium diversifolium Benth. & Native & 2 & $7.7 \pm 1.8$ & $20.37 \pm 18.5$ & \\
\hline & Andira inermis (W.Wright) DC. & Native & 10 & $6.6 \pm 3.3$ & $27.25 \pm 16.4$ & 20 \\
\hline & Cassia fistula L. & Exotic & 2 & $4.0 \pm 0.7$ & $10.50 \pm 2.7$ & \\
\hline & Cassia sp & Native & 1 & 4.2 & 9.87 & \\
\hline & Senna siamea (Lam.) H.S.Irwin \& Barneby & Exotic & 5 & $6.8 \pm 0.9$ & $42.78 \pm 4.5$ & 20 \\
\hline
\end{tabular}


Table 1. Continued.

\begin{tabular}{|c|c|c|c|c|c|c|}
\hline Family & Scientific Name & Origin & $\mathrm{N}$ individuals & Height $(m) \pm$ DPSD & $\mathrm{DAG}(\mathrm{m}) \pm \mathrm{SDDP}$ & $\begin{array}{c}\text { Infestation } \\
\text { frequency (\%) }\end{array}$ \\
\hline \multirow{2}{*}{ Fabaceae } & Dipteryx odorata (Aubl.) Willd. & Native & 1 & 5.0 & 11.46 & \\
\hline & Ormosia paraensies Ducke & Native & 3 & $10.9 \pm 2.4$ & $40.48 \pm 23.5$ & \\
\hline Leguminosae & Tamarindus indica L. & Exotic & 3 & $8.3 \pm 2.1$ & $30.66 \pm 10.4$ & \\
\hline Meliaceae & Azadirachta indica A.Juss. & Exotic & 4 & $5.9 \pm 1.0$ & $19.74 \pm 6.9$ & 25 \\
\hline Moraceae & Ficus benjamina L. & Exotic & 29 & $6.5 \pm 2.7$ & $49.22 \pm 23.7$ & 13.8 \\
\hline \multirow[b]{2}{*}{ Myrtaceae } & Syzygium cumini (L.) Skeels & Exotic & 1 & 10.7 & 58.89 & 100 \\
\hline & $\begin{array}{l}\text { Syzygium malaccense (L.) } \\
\text { Merr. \& L.M.Perry }\end{array}$ & Exotic & 9 & $8.2 \pm 2.7$ & $41.52 \pm 11.6$ & 55.6 \\
\hline Rutaceae & Citrus limon (L.) Osbeck & Exotic & 1 & 5.0 & 14.32 & \\
\hline Total & & & 310 & & & 19.3 \\
\hline
\end{tabular}

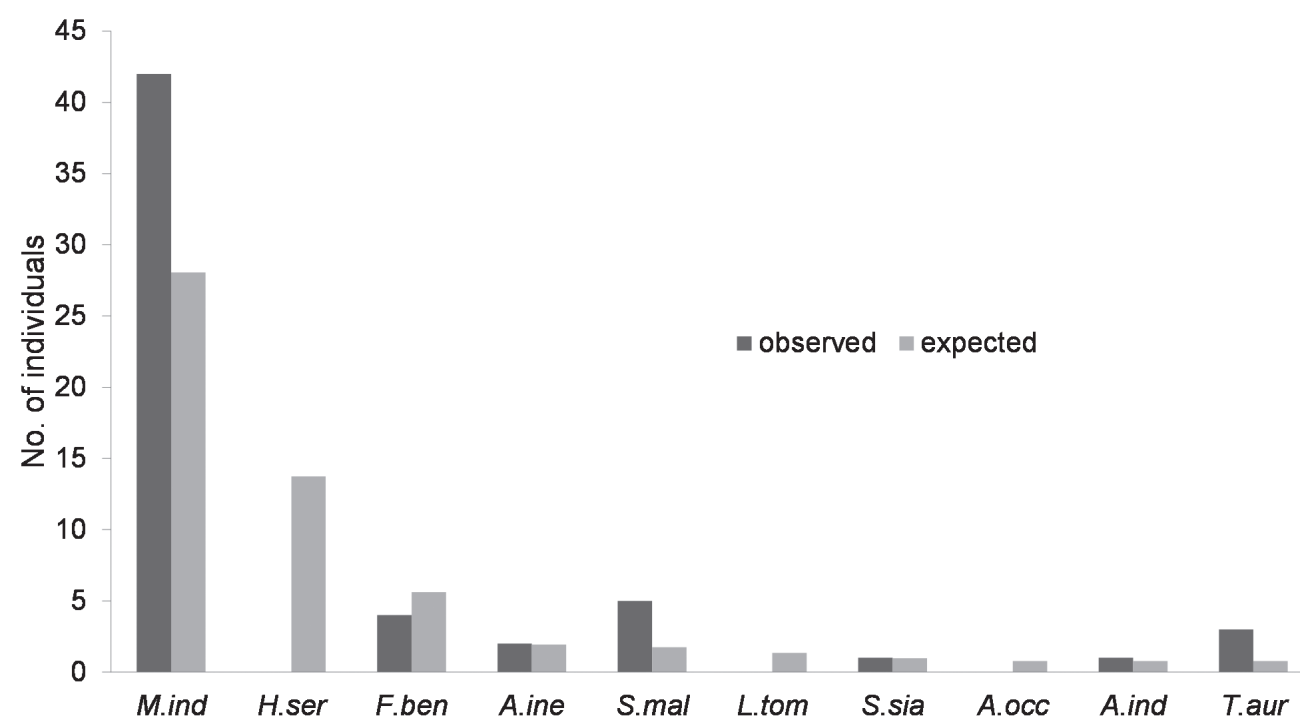

Figure 2. Ten most abundant tree species recorded in the three surveyed avenues of the urban area of the city of Santarém, state of Pará, Brazil, showing the observed number of individual trees infested by mistletoe (dark bars) and the expected number of infested individuals, based on their relative abundance (light gray bars). M.ind = Mangifera indica, H.ser = Handroanthus serratifolius, F.ben = Ficus benjamina, .. ine = Andira inermis, S. mal = Syzygium malaccense, L.tom = Licania tomentosa, S.sia $=$ Senna siamea, A.occ = Anacardium occidentale, A.ind $=$ Azadirachta indica, T.aur $=$ Tabebuia aurea.
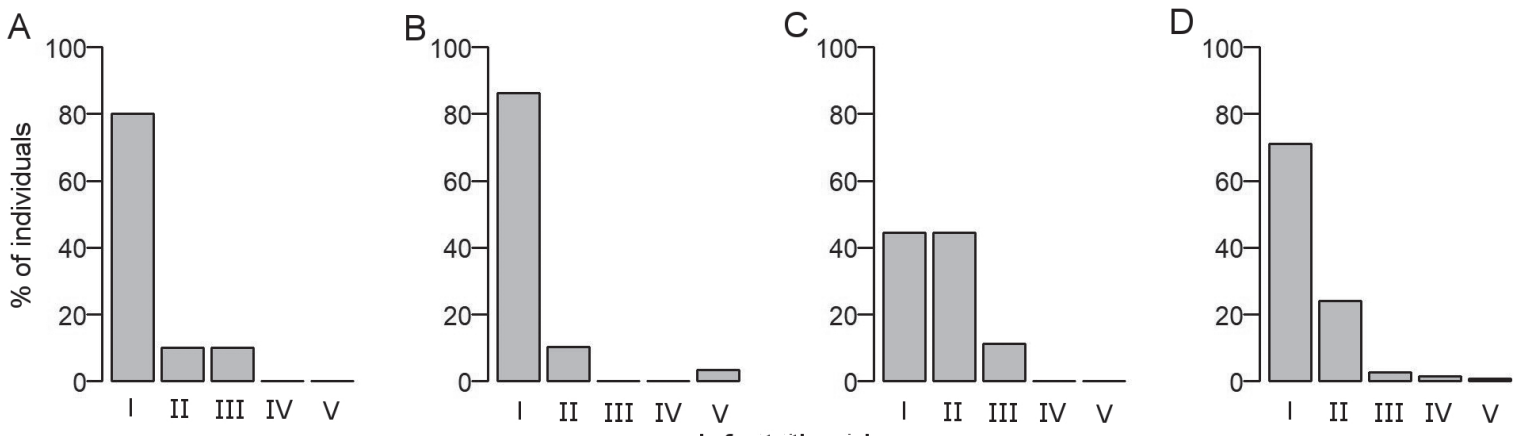

Figure 3. Intensity of infestation by Passovia theloneura of the four host species with the highest observed mistletoe: A - Andira inermis; B - Ficus benjamina; $\mathrm{C}$ - Syzygium malaccense and D - Mangifera indica. The five infestation classes refer to percentage of canopy infestation: I - no infestation; II - 1-25\%; III $26-50 \%$; IV - $51-75 \%$; and V - 76-100\%. 
Table 2. Epicortical root length, length of the main branch, and fresh and dry weight of epicortical roots and aerial parts of surviving mistletoe seedlings of Passovia theloneura after six months. Data from plants growing on Andira inermis and Mangifera indica hosts. Values are the mean \pm SD.

\begin{tabular}{lcccccc}
\hline Species & $\begin{array}{c}\text { Epicortical root I } \\
\text { ength }(\mathrm{mm})\end{array}$ & $\begin{array}{c}\text { Main stem } \\
\text { length }(\mathrm{mm})\end{array}$ & $\begin{array}{c}\text { Epicortical root } \\
\text { fresh weight }(\mathrm{g})\end{array}$ & $\begin{array}{c}\text { Aerial parts } \\
\text { fresh weight }(\mathrm{g})\end{array}$ & $\begin{array}{c}\text { Epicortical root dry } \\
\text { weight }(\mathrm{g})\end{array}$ & $\begin{array}{c}\text { Aerial parts dry } \\
\text { weight }(\mathrm{g})\end{array}$ \\
\hline M. indica & - & $17.5 \pm 15.1$ & - & $0.08 \pm 0.04$ & - & $0.02 \pm 0.02$ \\
A. inermis & $189.6 \pm 146.8$ & $108.5 \pm 88.5$ & $0,36 \pm 0,35$ & $1.6 \pm 2.0$ & $0,2 \pm 0,2$ & $0.6 \pm 0.8$ \\
\hline
\end{tabular}

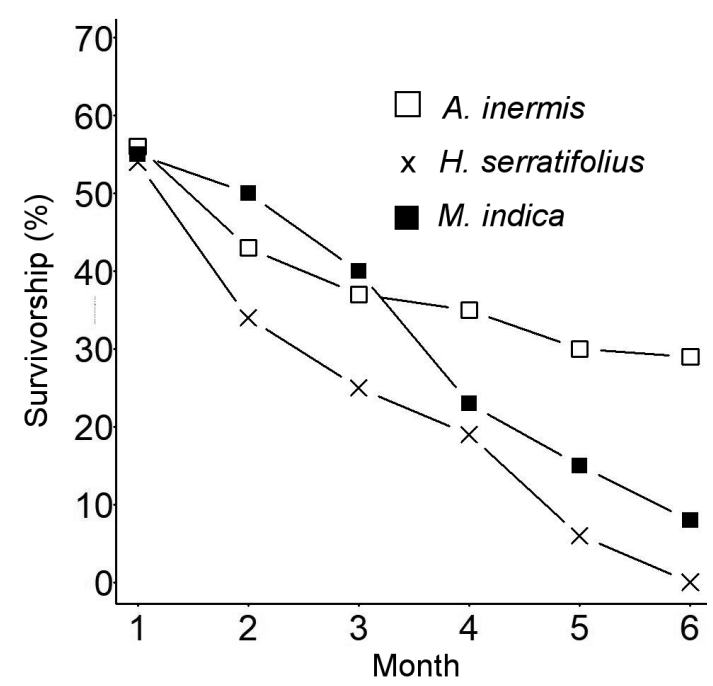

Figure 4. Survivorship of Passovia theloneura mistletoe seedlings on three tree species (Andira inermis, Handroanthus serratifolius and Mangifera indica) six months after seed inoculation.

\section{DISCUSSION}

Among the studies on the prevalence of infestation by mistletoes and their relationships with trees in urban areas in Brazil (Rotta et al. 2006; White et al. 2011; Sulevis and Biondi 2014; Leal et al. 2006; Maruyama et al. 2012), only one (Maruyama et al. 2012), investigated the mechanism of infestation experimentally. As a result, the information contained in many studies is not useful for devising effective management measures to combat the spread of mistletoe infestations in urban areas. In this study, we showed that some tree species may not be infested because they are not recognized as hosts by mistletoes during the stages of germination and establishment. We have also shown that highly infested species (e.g. M. indica) do not necessarily provide the best growth and development sites for mistletoes. Therefore, other factors likely explain the high degree of parasitism in this species.

The urban tree community of Santarém was characterized by the predominance of two species ( $M$. indica $46.7 \%$, and $H$. serratifolius $22.9 \%$ ). This pattern is similar to that found in several other Brazilian cities (Almeida and Rondon Neto 2010; Parry et al. 2012). In order to diversify the species assemblage, and minimize problems with pests and diseases, as well as infections by mistletoes, it is recommended that populations of individual species do not exceed $10-15 \%$ of the total urban tree population (Pivetta and Silva Filho 2002; Rocha et al. 2004). Mistletoes are parasites that spread easily in low diversity tree assemblages (Lavorel et al. 1999), and can become highly debilitating to their hosts (Aukema 2003). Consequently, a policy that favors planting a variety of tree species in public spaces can reduce the spread of mistletoe infestations and the costs of maintaining urban afforestation.

In addition to the dominance of only a few tree species along the surveyed avenues, half of these species were exotics, which is also similar to other studies carried out in Brazil (Almeida and Rondon Neto 2010; Kramer and Krupek 2012). Most of the species and individuals infested by mistletoes were of exotic origin, which reflects other studies that have shown that native species are less parasitized by mistletoes than exotic ones (Rotta et al. 2006; Maruyama et al. 2012; Sulevis and Biondi 2014). Several species of mistletoes infest exotic host species worldwide (Hawksworth 1974), and seem to prefer such species to native ones (Rotta 2001). Thus, in addition to increasing the variety of trees planted in public afforestations, it is advisable to use native tree species that are resistant to mistletoe infestations.

The species of greatest relative abundance ( $M$. indica), along with $S$. malaccense and the very uncommon $T$. aurea, all had higher than expected numbers of mistletoe-infested individuals. However, $H$. serratifolius, one of the most abundant species in the city, had no individuals infested by mistletoes. Observations elsewhere in the city apart from this study confirm this pattern. These results indicate that locally more common hosts are not always the most highly parasitized (Fadini 2011). This differs from what has been suggested by previous studies (e.g. Roxburgh and Nicolson 2005).

The four most abundant host species in the survey had generally low crown infestation intensity by $P$. theloneura, which corroborates results of other studies of mistletoes in urban afforestations in Brazil (Leal et al. 2006; White et al. 2011). Low infestation intensity allows control using lowcost methods, such as manual removal and pruning, which are unlikely to damage the host trees (White et al. 2011). Observations made in our study area, however, suggest that, if management is not frequent, $P$. theloneura can cover the 
entire canopy of the tree, a build-up that can lead to eventual host death.

Several studies have shown that, while germination of mistletoes is little affected by the substrate characteristics, establishment and growth are extremely dependent on the type of host (Maruyama et al. 2012). In our study, the majority of $P$. theloneura seeds germinated readily on the three evaluated tree species, but only established on $M$. indica and A. inermis. No seeds successfully established on $H$. serratifolius, which is one of the species most commonly used for urban afforestation in Santarém. Handroanthus serratifolius has an ipein in its bark (Sousa et al. 2007), and this chemical compound inhibits or hinders the germination of mistletoe seeds (Rotta et al. 2006). Consequently, at least based on the criterion of "resistance to mistletoes", H. serratifolius is a species that should be highly recommended for urban afforestation programs in Santarém.

Mangifera indica was the most parasitized species in this study. As a result, the survival rate of planted seeds was expected to be highest on this host. However, $P$. theloneura seeds had a higher survival rate on $A$. inermis, which had a number of infested individuals similar to that expected from its frequency in the tree assemblage. Thus, there was no relationship between the infection prevalence and seedling survival for these mistletoes. This corroborates observations by Roxburgh and Nicolson (2005), who also failed to find correlation between the survival of mistletoes and the prevalence of infestation for two species studied in Africa.

Differences were also observed in the seedlings that survived until the end of the six-month growth experiment. The seedlings growing on A. inermis showed strong development of both aerial parts and epicortical roots. The individuals established on $M$. indica showed no epicortical root development during the study period and biomass values of aerial parts were much lower than those for seedlings growing on $A$. inermis. Morphological characteristics of the host, such as the thickness of the bark, can influence the success of mistletoe establishment, due to mechanical resistance to haustoria penetration (Yan 1993; Hishe and Abraha 2013). It may therefore be significant that $M$. indica has a hard and thick bark, which may make it difficult for $P$. theloneura seedlings to establish after germination. In addition, the rates of physiological parameters of $M$. indica, such as $\mathrm{CO}_{2}$ assimilation, are lower than those of $A$. inermis, and this too may disrupt successful mistletoe parasitism (Quang-Vuong Le et al. 2014). Together, these characteristics may explain the stronger development of seedlings on $A$. inermis, yet they do not explain why $M$. indica is the most infested host species in our sample.

Infestation patterns of mistletoes are determined mainly by the rate of seed deposition by dispersers (Roxburgh and Nicolson 2005). Thus, given the results of our germination test, it is likely that disperser preference for $M$. indica is responsible for the observed differences in infestation incidence between
M. indica and A. inermis. Notably, M. indica individuals in our sample were taller, and their canopy architecture makes them highly attractive to birds (Hishe and Abraha 2013). In addition, the fruits of this species attract a wide variety of frugivorous bird species, which may also deposit mistletoe seeds on $M$. indica branches when the fruiting season of the two species overlap. In contrast, $A$. inermis individuals are shorter, and have fruits consumed only by bats and rodents (Mabberley 1997). Thus, it is likely that birds use individual A. inermis only for perching, reducing the chances of mistletoe seed deposition.

\section{CONCLUSIONS}

The urban tree community of Santarém is characterized by the predominance of two species, which, together, accounted for $70 \%$ of sampled individuals. Mistletoes were more frequent on exotic host species, yet the infestation intensity was low. The most frequent mistletoe species on the urban trees in Santarém was $P$. theloneura, although a minimal infestation by $O$. florulentus also occurred. Experimental seed inoculation with the mistletoe $P$. theloneura on the native tree $H$. serratifolius showed these two species to be incompatible. Results also indicated that infestation patterns in $M$. indica and $A$. inermis are likely to be the result of disperser behavior. From the observed patterns of growth and development of mistletoes on the hosts, it is possible to suggest management strategies for mistletoe control in urban afforestations. We recommend pruning at shorter intervals for species such as $A$. inermis, on which mistletoes are fast-growing, and pruning at longer intervals for species like $M$. indica, on which mistletoe growth rates are slow.

\section{ACKNOWLEDGMENTS}

We thank Everton Almeida for supplying materials and equipment, Angélica Souza for help in the field at all stages of the study, Arlison B. Castro for help with the seed inoculation experiment. To Mr. Juca, Chieno Suemitsu and Leandro Giacomin for botanical identification of host species. Everton Almeida, Ricardo Scoles and two anonymous reviewers made suggestions on previous versions of the manuscript. Adrian Barnett helped with the English. Claudia Keller made a careful review of the final version. FPS received a fellowship from the Universidade Federal do Oeste do Pará. This is the publication number 22 of the Parasitic Plants Research Group Technical Series.

\section{REFERENCES}

Almeida, D.N.; Rondon Neto, R.M. 2010. Análise da arborização urbana de duas cidades da regiáo norte do Estado de Mato Grosso. Revista Arvore, 34: 899-906. 
Alvares, C.A.; Stape, J.L.; Sentelhas, P.C.; Gonçalves, J.L.M.; Sparovek, G. 2014. Köppen's climate classification map for Brazil. Meteorologische Zeitschrift, 22: 711-728.

APG IV. 2016. An update of the Angiosperm Phylogeny Group classification for the orders and families of flowering plants: APG IV. Botanical Journal of the Linnean Society, 181: 1-20.

Arruda, R.; Fadini, R.F.; Carvalho, L.N.; Del-Claro, K.; Mourão, F.A.; Jacobi, C.M.; Teodoro, G.S.; Van den Berg, E.; Caires, C.S.; Dettke, G.A. 2012. Ecology of neotropical mistletoes: an important canopy-dwelling component of Brazilian ecosystems. Acta Botanica Brasilica, 26: 264-274.

Aukema, J.E. 2003. Vectors, viscin, and Viscaceae: mistletoes as parasites, mutualists, and resources. Frontiers in Ecology and the Environment, 1: 212 -219.

Calvin, C.L.; Wilson, C.A. 2006. Comparative morphology of epicortical roots in Old and New World Loranthaceae with reference to root types, origin, patterns of longitudinal extension and potential for clonal growth. Flora, 201: 51-64.

Cazetta, E.; Galetti, M. 2003. Ecologia das ervas-de-passarinho. Ciência Hoje, 33: 72-74.

Cooney, S.J.N.; Watson, D.M.; Young, J. 2006. Mistletoe nesting in Australian birds: a review. Emu, 106: 1-12.

Diáz-Limón, M.P.; Cano-Santana, Z.; Queijeiro-Bolaños, M.E. 2016. Mistletoe infection in an urban forest in Mexico City. Urban Forestry \& Urban Greening, 17: 126-134.

Faria, J.L.G.; Monteiro, E.A.; Fisch, S.T.V. 2007. Arborização de vias públicas do município de Jacareí-SP. Revista da Sociedade Brasileira de Arborização Urbana, 2: 20-33.

Flora do Brasil. 2020 under construction. Jardim Botânico do Rio de Janeiro (http://floradobrasil.jbrj.gov.br/). Accessed on 25/05/2017.

Fournier, L.A. 1974. Un método cuantitativo para la medición de características fenológicas en árboles. Turrialba, 24: 422-423.

Fadini, R.F. 2011. Non-overlap of hosts used by three congeneric and sympatric loranthaceous mistletoe species in an Amazonian savanna: host generalization to extreme specialization. Acta Botanica Brasilica, 25: 337-345.

Gairola, S.; Bhatt, A.; Govender, Y.; Baijnath, H.; Proches, S.; Ramdhani, S. 2013. Incidence and intensity of tree infestation by the mistletoe Erianthemum degrei (Eckl. \& Zeyh.) V. Tieghem in Durban, South Africa. Urban Forestry \& Urban Greening, 12: 315-322.

Hawksworth, F.G. 1974. Mistletoes on introduced trees of the world. Agricultural handbook nr. 469. USDA Forest Service, Washington DC, 49p.

Hishe, M.; Abraha, B. 2013. Mistletoe infection of woody plant species at Bahir Dar University main campus, Bahir Dar, Ethiopia. Ethiopian Journal of Science, 36: 119-124.

IBGE. 2010. (http://cidades.ibge.gov.br/xtras/perfil. php?codmun=150680). Accessed on 26/01/2015.

Lavorel, S.; Smith, M.S.; Reid, N. 1999. Spread of mistletoes (Amyema preissii) in fragmented Australian woodlands: a simulation study. Landscape Ecology, 14: 147-160.
Leal, L.; Bujokas, W.M.; Biondi, D. 2006. Análise da infestação de erva-de-passarinho na arborização de ruas de Curitiba, PR. Floresta, 36: 323-330.

Loboda, C.R.; De Angelis, B.L.D. 2005. Áreas verdes públicas urbanas: conceitos, usos e funçôes. Ambiência, 1: 125-139.

Kramer, J.A.; Krupek, R.A. 2012. Caracterização florística e ecológica da arborizaçáo de praças públicas do município de Guarapuava, PR. Revista Árvore, 36: 647-658.

Mabberley, D.J. 1997. The plant-book: a portable dictionary of the vascular plants. Cambridge University Press, Cambridge, 858p.

Maruyama, P.K.; Mendes-Rodrigues, A.C.; Alves-Silva, E.; Cunha, A.F. 2012. Parasites in the neighbourhood: interactions of the mistletoe Phoradendron affine (Viscaceae) with its dispersers and hosts in urban areas of Brazil. Flora, 207: 768-773.

Mathiasen, R.L.; Nickrent, D.L.; Shaw, D.C.; Watson, D.M. 2008. Mistletoes pathology, systematics, ecology, and management. Plant Disease, 92: 988-1006.

Modro, A. F.H.; Message, D.; Luz, C.F.P.; Meira-Neto, J.A.A. 2011. Flora de importância polinífera para Apis mellifera na região de Viçosa, MG. Revista Árvore, 35: 1145-1153.

Monteiro, R.F.; Martins, R.P.; Yamamoto, K. 1992. Host specificity and seed dispersal of Psittacanthus robustus (Loranthaceae) in south-east Brazil. Journal of Tropical Ecology, 8: 307-314.

Nickrent, D.L. 2011. Santalales (including mistletoes). In: Encyclopedia of Life Sciences 689 (ELS). John Wiley \& Sons, Ltd., Chichester, p.1-6.

Parry, M.M.; Silva, M.M.; Sena, I.S.; Oliveira, F.P.M. 2012. Composição florística da arborizaçấo da cidade de Altamira, Pará. Revista da Sociedade Brasileira de Arborização Urbana, 7: 143-158.

Pivetta, K.F.L; Silva Filho, D.F. 2002. Boletim acadêmico: Arborização urbana. Jaboticabal, São Paulo. 69p.

Quang-Vuong Le, Q.V.; Tennakoon K.U.; Metali, F.; Lim, L.B.L.; Bolin, J.F. 2014. Host specific variation in photosynthesis of an obligate xylem-tapping mistletoe Dendrophthoe curvata in a Bornean heath forest. Nordic Journal of Botany, 34: 235-243.

R Development Core Team 2015. R: a language and environment for statistical computing. R Foundation for Statistical Computing, Vienna, Austria. (http://www.R-project.org).

Rocha, R.T; Leles, P.S.S; Oliveira-Neto, S.N. 2004. Arborização de vias públicas em Nova Iguaçu, RJ: o caso dos Bairros Rancho Novo e Centro. Revista Árvore, 28: 599-607.

Rotta, E. 2011. Erva-de-passarinho (Loranthaceae) na arborização urbana: Passeio Público de Curitiba, um estudo de caso. Doctoral thesis, Universidade Federal do Paraná, Curitiba, Brazil. 135p.

Rotta, E.; Araújo, A.J.; Oliveira, Y.M.M. 2006. A infestação da vegetação arbórea do Passeio Público de Curitiba, Paraná, por erva-de-passarinho: um estudo de caso. Boletim de Pesquisa e Desenvolvimento/Embrapa Florestas, 26: 1-25.

Roxburgh, L.; Nicolson, S.W. 2005. Patterns of host use in two African mistletoes: the importance of mistletoe-host compatibility and avian disperser behavior. Functional Ecology, 19: 865-873. 
Santarém (Prefeitura). 2015. (http://www.santarem.pa.gov.br/ conteudo/?item $=116 \& \mathrm{fa}=62$ ). Accessed on 26/01/2015.

Silva-Filho, D.F.; Pizetta, P.U.C.; Almeida, J.B.S.A.; Pivetta, K.F.L.; Ferraudo, A. 2002. Banco de dados relacional para cadastro, avaliação e manejo da arborização em vias públicas. Revista Árvore, 26: 629-642.

Sousa, M.A.R.; Moutinho, V.H.P.; Silva, S.S. 2007. Levantamento das espécies comercializadas vernacularmente como cumaru no Estado do Pará. Revista Brasileira de Biociências, 5: 81-83.

Sulevis, C.; Biondi, D. 2014. Análise morfológica de espécies da arborização de ruas de Curitiba-PR e a infestação por ervade-passarinho. Revista da Sociedade Brasileira de Arborização Urbana, 9: 1-17.

Uchôa, P.W.S. 2011. Estudo de variaçôes termo-higrométricas de cidade equatorial devido ao processo de urbanização: o caso de SantarémPA. Master's thesis, Universidade Federal do Oeste do Pará, Santarém, Brazil. 77p.

Watson, D.M. 2001. Mistletoe- a keystone resource in forests and woodlands world-wide. Annual Review of Ecology and Systematics, 32: 219-49.
Watson, W.T.; Martinez-Trinidad, T. 2006. Strategies and treatments for leafy mistletoe (Phoradendron tomentosum (DC.) Engelm ex Gray) suppression on cedar elm (Ulmus crassifolia Nutt.). Arboriculture \& Urban Forestry, 32: 265-270.

White, B.L.A; Ribeiro, A.S; White, L.A.S; Nascimento-Jr., J.E. 2011. Análise da ocorrência de erva-de-passarinho na arborização da Universidade Federal de Sergipe, Campus São Cristóvão. Floresta, 41: 1-8.

Yan, Z. 1993. Resistance to haustorial development of two mistletoes, Amyema preissii (Miq.) Tieghem and Lysiana exocarpi (Behr.) Tieghem ssp. exocarpi (Loranthaceae), on host and nonhost species. International Journal of Plant Sciences, 154: 386-394.

Received: 25/02/2017

Accepted: 21/08/2017 
